\section{UK's Darwin Initiative}

The Darwin Initiative for the Survival of Species seeks to help safeguard the world's biodiversity by drawing on British strengths in this area to assist those countries that are rich in biodiversity but poor in financial resources. It was first announced by the UK Government at the Earth Summit held in Rio de Janeiro in June 1992.

It aims to fund collaborative projects between British institutions and partners in developing countries and whose work can have a real impact on the ability of the host country to meet its obligations under the Biodiversity Convention. It also aims to build institutional capacity, provide training, carry out scientific research and increase environmental education or awareness.

So far in seven rounds of funding, the Initiative has committed $£ 21$ million to almost 200 projects in over 80 countries. About 80 British institutions have been involved. A typical project lasts for up to 3 years and most of the major UK biodiversity institutions (scientific institutions, universities and NGOs) have received funding.

On 11 March 1999, The Rt Hon. Michael Meacher MP, Minister for the Environment, announced 26 new biodiversity projects. These new projects will take place in over 20 countries world-wide, including four UK Overseas Territories. They range from studies on individual species to topical issues, including sharing the benefits arising from the use of plants and animals. The projects include:

- Building the local know-how for biodiversity conservation through a system of protected areas in Anguilla. - Funding for a research project to conserve western lowland gorillas in Gabon.

- Setting up a pilot project to maintain a sustainable waste management plan for a hotel and village on a coral reef in Fiji.

- Establishing and maintaining the local biodiversity for small coffee producers in El Salvador.

- Conserving and cultivating medicinal plants for use by local people in Ghana.

- Studying the conservation of coastal vegetation in Lebanon.

The indications coming from the monitoring and evaluation of the programme are encouraging. For a relatively small amount of funding (about $£ 120,000$ ), the projects usually more than meet their objectives as well as provide a platform from which further work can be done. By 1997, well over 2000 people had received training and 70 sets of training material had been prepared. Nineteen permanent education and/or research facilities have been established and 19 guides to assist with species identification produced. In addition, over 20 species or habitat management plans have been delivered to the appropriate authorities.

\section{New Biodiversity Agenda for the UK's Overseas Territories}

The Overseas Territories of the UK have a rich and varied biodiversity, which is increasingly under threat. Now, for the first time, the UK Government has set out a clear policy statement on the environment in these scattered Territories. The policy is contained within Partnership for Progress and Prosperity: Britain and the Overseas Territories, a Government White Paper published in March 1999*. This states that, 'The common objective must be to use the environment of the Overseas Territories to provide benefits to the people in them, and to conserve our global heritage by managing sustainably all the Overseas Territories' natural resources'.

The White Paper has been broadly welcomed by the UK Overseas Territories Conservation Forum. Fauna \& Flora International (FFI) plays an active role as a member of this Forum in planning support for conservation activities in the Overseas Territories. Currently, FFI is directly involved in supporting biodiversity conservation in Anguilla, the British Indian Ocean Territory, the British Virgin Islands and Montserrat. At a policy level, FFI has supported the Forum's call for stronger UK Government commitment to conservation in the Territories for the past decade.

The clarification on division of responsibilities for environmental matters within the White Paper is one aspect that is particularly welcomed. The UK Government specifies that it will assist with updating environmental legislation, help the Territories integrate environmental management into development planning, promote co-operation between the Territories and other small island states, and represent their interests in international environmental agreements and negotiations. The Territories, in turn, will be expected to develop crosscutting strategies for sustainable development, which incorporate specific targets for species and ecosystem conservation, and they will be encouraged to look at economic incentives for environmental management. As the White Paper acknowledges, these responsibilities are not new but they have not always been adequately addressed in the past. 
Also strongly welcomed is the increased funding that the Government will make available to support environmental projects in the Overseas Territories. This will be directed towards priority activities incorporated in an Environmental Charter, which will be drawn up through a broad consultative process. Much work remains to be done to ensure that all the Territories are in a position to meet international conservation obligations already well established in the UK, but the White Paper provides a firm basis on which to move forward.

\section{Sara Oldfield, Fauna E Flora International}

*Partnership for Progress and Prosperity: Britain and the Overseas Territories (March 1999). The Stationery Office Ltd, London, UK.

\section{The BP Conservation Programme winners for 1999}

Fifteen student teams around the world won awards in this year's BP Conservation Programme, which supports field research on endangered species. The Rt Hon. Michael Meacher MP, Minister for the Environment, presented the awards on Wednesday 28 April 1999 at the Commonwealth Institute, London.

Of the 15 winning teams, three are based at UK universities (Aberdeen, Durham and Oxford, with expeditions to Ghana, Madagascar and the Phillipines, respectively) and 12 are from overseas, undertaking field research projects in their home countries of Argentina (two teams), China (three teams), Colombia, Ecuador, French Polynesia, Malaysia, Mexico, Russia, Turkey and Venezuela. The awards comprise not only funding but also practical training and ongoing advice to help the students undertake the best research possible to underpin global conservation initiatives.

A $£ 12,000$ award for the best 'Follow-up' proposal submitted from last year's winning projects was presented to a team from Venezuela and Colombia to continue research to protect endangered green, loggerhead, olive ridley and leatherback turtles. Four winning projects in three award categories-Threatened Species (two winners), Tropical Forests, and Wetlands Grasslands, Savannahs and Deserts each received $£ 5000$, while 10 teams each received Runner-up awards of $£ 3000$.

Celebrating its 14th year, the Programme is organized by BirdLife International and Fauna \& Flora International and for the ninth successive year is supported by BP Amoco. The winners were chosen from a record number of 230 applications from student teams in 62 countries.

The BP Conservation Programme is open to students in full- or part-time education anywhere in the world.
The selection procedure is stringent, demanding high standards of scientific research and full collaboration with the host country in all the conservation initiatives it supports. For further Programme information contact: Katharine Gotto, Programme Manager. Tel.: + 44 (0)1223 277318; E-mail: katharine.gotto@birdlife.org.uk

The winning projects $£ 12,000$ Follow-up Award Winner

Capacity building for research and conservation of endangered sea turtles in Venezuela and Colombia. Project Leaders: Hedelvy Guada, Universidad Simon Bolivar, Venezuela and Diego Amorocho, Convenio FES-WIDECAST, Colombia.

$£ 5000$ Threatened Species Category Awards Distribution, relative abundance and commercial trade of tortoises in Peninsular Malaysia. Project Leader: Reuben Sharma, Putra University, Malaysia.

Eurasian Bridge '99-Bat Research in north-western Turkey. Project Leader: Arpat Ozgul, Bogazici University, Turkey.

$£ 5000$ Tropical Forests Category Award Polillo '99; An Oxford-Los Banos University expedition. Project Leader: Katie Hampson, Oxford University, UK.

$£ 5000$ Wetlands, Grasslands, Savannahs \& Deserts Category Award

Endangered water-birds conservation and their habitat management in Liaohe delta wetland, China. Project Leader: Li Xiaowen, Institute of Applied Ecology, Shenyang, China.

\section{Policy for sustainable use of wild species on communal lands in Africa}

The Government of Zimbabwe Communal Areas Management Programme for Indigenous Resources (CAMPFIRE) was set up in the 1980s in recognition of the fact that as long as wildlife on communal land remained the property of the state, no one would invest in it as a resource. The wild animals on communal lands frequently caused problems for farmers but offered no benefits. The CAMPFIRE programme provided the legislative framework that enabled people living in communal lands to claim ownership of wildlife on their lands and to benefit from its use. Tenural rights over wildlife were decentralized from central to local government authorities, which in turn were able to enter into joint management agreements with local communities, including those for the development of profitable and sustainable wildlife use strategies. As a result Zimbabwe 
has witnessed a threefold expansion in the land area available for wildlife management-from 12 to 33 per cent-and a rise in wildlife numbers. The programme has benefited 2 million people. This policy of decentralizing authority over wildlife has now been adopted by many African countries.

In recognition of the key role that appropriate tenure arrangements have to play in sustainable-use programmes for wild species on communal lands of southern Africa, the Africa Resources Trust has produced a briefing document to provide decision makers with an overview of key issues and policy options for the development of appropriate tenure systems/property rights. It provides an introduction to key concepts and terminology in the debate, an overview of current trends, a summary of the critical policy issues and options of relevance to tenural arrangements, and additional recommended literature.

Source: Rihoy, L. (1999) Policy Brief: Natural Resources Tenure in Africa. Africa Resources Trust, Brussels Office, Rue Jules Lejeune 32, 1050 Brussels, Belgium.

\section{The IUCN Red List Categories-discussion continues}

The 1996 IUCN Red List of Threatened Animals and The World List of Threatened Trees both used revised categories of threat introduced by IUCN in 1994. These categories aimed to introduce a more quantitative and objective assessment of threats to species than had been possible previously. To begin with, these revised categories were used only at a global scale, but their adoption at a regional and national level is now becoming more widespread.

A seminar on 17-18 March 1998 in Leiden, the Netherlands, reviewed the relevance and use of IUCN's revised threat categories. The resultant publication* contains 15 papers, some reviewing general species conservation issues and others examining the application of the categories to specific plant and animal groups, namely tree species, African fruit bats, antelopes, orchids and megapodes.

The introduction of revised categories of threat is part of a development to make the whole process of threatened status assessments more rigorous and scientific. Increasingly, it is not enough simply to say a species is threatened: concrete evidence is needed. The revised threat categories are constantly being tested in various situations with the aim of improving their applicability and acceptability. This set of papers gives an excellent overview of the current issues and problems as well as showing how the categories can be used for different species groups. As such it will be of interest to all those involved in the review process for the IUCN Red Lists or those who are interested in using the revised categories at a regional or national scale.

Simon Mickleburgh, Fauna $\mathcal{E}$ Flora International

*Iongh, H. de \& Prins, H. (eds) (1999) International Seminar on Species Conservation: The IUCN Red List Categories Discussed. Mededelingen No.33, Nederlandsche Commissie voor Internationale Natuurbescherming. 